\title{
Carbon and nitrogen in forest floor and mineral soil under four forest species in the Mediterranean region
}

\author{
Carbono y nitrógeno en horizontes orgánicos y minerales de suelos desarrollados bajo \\ cuatro especies forestales en la región mediterránea \\ Carbono e nitrogénio nos horizontes orgânicos e minerais dos solos desenvolvidos sob \\ quatro espécies florestais na região Mediterrânica
}

\section{Fonseca . $^{@}$}

ffonseca@ipb.pt

\section{de FigueiredoT.}

@ Corresponding Author

CIMO-Centro de Investigação de Montanha, Escola Superior Agrária,

Received: 12.04.2017 | Revised: 22.02.2018 | Accepted: 27.02.2018

\section{ABSTRACT}

The organic and mineral horizons of soils are of great importance in $\mathrm{C}$ and $\mathrm{N}$ storage in forest areas. However, knowledge of the effects of forest species on the stocks of these elements is still scarce, especially in Portugal. In order to contribute to this knowledge, a study was carried out in forest stands of Pinus pinaster Aiton (PP), Pinus nigra Arnold (PN), Pseudotsuga menziesii (PM) and Castanea sativa Miller (CS), installed in the 1950s in northern Portugal. Sampling areas with similar topography, lithology and climate were selected, in order to better identify hypothesized differences in $\mathrm{C}$ and $\mathrm{N}$ storage due to forest species effect. In each stand, 15 sites were selected randomly and the forest floor (organic layers) was collected in a $0.49 \mathrm{~m}^{2}$ area. The layers $\mathrm{H}, \mathrm{L}$ and $\mathrm{F}$ of the forest floor were identified and, for $\mathrm{L}$ and $\mathrm{F}$, their components were separated in leaves, pine cones/chestnut husks and branches. At the same sites, soil samples were also collected at 0-10 and 10-20 cm depth. At these depths, undisturbed samples were also collected for bulk density determination. The concentrations of $\mathrm{C}$ and $\mathrm{N}$ were determined in forest floor and mineral components of the soil, and converted in mass per unit area. The quantity of $\mathrm{C}$ storage per unit area followed the sequence $\mathrm{PN}>\mathrm{PM}>\mathrm{CS}>\mathrm{PP}$, while for $\mathrm{N}$ the sequence was $\mathrm{CS}>\mathrm{PM}>\mathrm{PN}>\mathrm{PP}, \mathrm{OM}$ and $\mathrm{PP}$ keeping the same relative position in the sequence in both $\mathrm{C}$ and $\mathrm{N}$ concentrations. The PM and CS species store similar amounts of $\mathrm{C}$ and $\mathrm{N}$, and about $90 \%$ of these elements is found in the upper $20 \mathrm{~cm}$ of the mineral soil. In PN and PP species, the contribution of forest floor to the storage of these elements is more expressive than in the other species, but lower than $30 \%$ in all cases.

\section{RESUMEN}

Los horizontes orgánicos y minerales de los suelos forestales tienen una gran importancia en el almacenamiento de $C$ y N. Sin embargo, aún existe un escaso conocimiento sobre los efectos que las especies forestales pueden tener en la retención de estos elementos, particularmente en la región de montaña del Norte de Portugal. En este estudio se ha diseñado un muestreo aleatorio en parcelas situadas en la vertiente occidental de la Sierra Padrela, cerca de Vila Real, para las especies Castanea sativa Miller (CS) y Pinus pinaster Aiton (PP), con una alta representación en el norte del país, y Pseudotsuga menziesii (Mirb.) Franco (PM) y Pinus nigra Arnold (PN), con menor representación pero con cierto interés forestal. En la selección de zonas de muestreo se ha buscado características similares atendiendo a la edad de la masa, topografía, litología y clima, con el fin de reducir el efecto de otras variables y poder identificar 
mejor las posibles diferencias en el almacenamiento de $C y N$ debido únicamente a la especie. Para cada especie se han seleccionado 15 puntos de medición al azar y se han recogido muestras de material orgánico (horizonte orgánico) en un área de 0,49 $\mathrm{m}^{2}$ por punto. La recogida de esta muestra ha obedecido a criterios morfológicos y se han separado en las capas $L, F y H$. A su vez, en las capas $L$ y $F$ se han separado tres fracciones: hojas, conos o erizos y ramas. Además, en los mismos puntos se han recogido muestras de suelo a profundidades de 0-10 y 10-20 cm, asi como muestras inalteradas para la determinación de la densidad aparente. Posteriormente se ha determinado la concentración de $C y N$ en todas las muestras (horizontes orgánicos y minerales), transformándolas en masa por unidad de área. Los resultados obtenidos muestran que la cantidad de C por unidad de área sigue la secuencia $P N>P M>C S>P P$ y $C S>P M>P N>P P$ para el $N$. Las especies $P M$ y $C S$ almacenan cantidades idénticas de $C$ y $N$, y alrededor de 90\% de la cantidad de estos elementos se encuentran en el suelo. En el caso de las especies PN y PP la contribución de los horizontes orgánicos en la retención de estos elementos es más significativa que en el otras, pero siempre menor que $30 \%$.

\section{RESUMO}

Os horizontes orgânicos e minerais dos solos florestais apresentam elevada importância no armazenamento de $C$ e N. No entanto, o conhecimento dos efeitos das espécies florestais na retenção destes elementos é ainda escasso, principalmente em Portugal. Com o propósito de contribuir para este conbecimento realizou-se um estudo em povoamentos de quatro espécies florestais instalados na década de 50 do século XX na vertente poente da Serra da Padrela, próximo de Vila Pouca de Aguiar. Duas das espécies apresentam elevada representação na região Norte de Portugal, Castanea sativa Miller (CS) e Pinus pinaster Aiton (PP) e duas, embora com menor representatividade, evidenciam interesse silvicola, Pseudotsuga menziesii (Mirb.) Franco (PM) e Pinus nigra Arnold (PN). Na seleç̧ão das áreas de amostragem, procuraram-se características semelhantes no que toca a topografia, litologia e clima, de modo a reduzir o efeito de outras variáveis e a melhor identificar as possiveis diferenças no armazenamento de $C e N$ devidas à espécie florestal. Em cada povoamento, foram seleccionados 15 locais ao acaso e colbido o material orgânico (horizonte orgânico) numa área de $0,49 \mathrm{~m}^{2}$ por local. A colbeita do horizonte orgânico obedeceu a critérios morfológicos tendo sido separado nas camadas $L, F$ e $H$. As camadas $L$ e F, por sua vez, foram separadas em três fraç̧ôs: agulhas ou folhas, pinhas ou ouriços e ramos. Nos mesmos locais foram ainda colbidas amostras de solo nas profundidades 0-10 e 10-20 cm. Nestas profundidades colberam-se também amostras não perturbadas para determinação da densidade aparente do solo. As concentraçôes de C e N foram determinadas em todas as amostras (horizontes orgânicos e minerais) e convertidas em massa por unidade de área. A massa de $C$ por unidade de área segue a sequência $P N>P M>C S>P P$, mantendo as espécies $P M$ e $P P$ a mesma tendência para o $N$ que segue a sequência $C S>P M>P N>P P$. As espécies $P M$ e $C S$ armazenam quantidades idênticas de $C$ e $N$, sendo que cerca de $90 \%$ da quantidade destes elementos se encontra no solo. No caso das espécies PN e PP o contributo dos horizontes orgânicos na retenção destes elementos é mais expressivo do que nas restantes mas sempre inferior a 30\%.

\section{Introduction}

Forest species litter production and litter quality have a recognized importance in the accumulation, type and distribution of soil organic matter formed in the topsoil horizon. In turn, they determine a series of processes that influence soil properties, pedogenesis, and the productivity and sustainability of ecosystems (Oostra et al. 2006; Fisher and Binkley 2012). Forest species affect soil development both directly through the chemistry of the litter and indirectly through the effect of the litter on biological community composition (Reich et al. 2005; Kooch et al. 2017). The nutrient fluxes to the soil are related to litter quality, particularly the proportions of C and N (Fisher and Binkley 2012; Park 2015). Decomposition is an important component of the $\mathrm{C}$ and $\mathrm{N}$ cycles (Shaw and Harte 2001) and is closely related to the 
biological activity that, among several factors, depends on the climatic conditions, chemical and structural composition of organic residues and nutrient availability (Bargali et al. 2015). For similar climatic conditions, nature and quantity of litter have an important role in forest floor formation and energy transfer between plants and soil (Santa-Regina 2001; Shaw and Harte 2001; Marty et al. 2017). Also, the forest floor plays a crucial role in the hydrological processes and can influence considerable processes at an ecosystem level, due to their location at the interface of the atmosphere and the mineral soil (Keith et al. 2010).

The forest floor has a heterogeneous composition and can be divided into Litter layer (L), Fermentation layer (F) and Humus layer (H), corresponding to forest litter at various stages of decomposition (Wesemael 1993; Wardle 1993). Decomposition rates of plant residues can be slower or faster, depending on their nature. In general, it is accepted that organic residues from coniferous species decompose slower than broadleaved species, for example, due to the presence of non-hydrolyzable polyphenolic compounds in litter (Berg and McClaugherty 2003; Díaz-Pinés et al. 2011). On the other hand, fast-growing species would accumulate $C$ faster than slow-growing species, but several studies have shown that replacement leads to a C loss, mainly in the mineral soil (Schroth et al. 2002; Wang and Wang 2007; Vallet et al. 2009). Owing to increasing emphasis on ecosystem services, the knowledge of the differences among forest species regarding $C$ sequestration should be a decision support tool when introducing new forest species and can be used strategically to reach environmental goals (Oostra et al. 2006; Schulp et al. 2008; Vallet et al. 2009; Vesterdal et al. 2013).

The main objective of the present study was to quantify the effects of four forest species (Pinus pinaster Aiton (PP) and Castanea sativa Miller (CS), which are well represented in North Portugal; Pinus nigra Arnold (PN) and Pseudotsuga menziesii (Mirb.) Franco (PM), with lower coverage but with forestry interest) on $\mathrm{C}$ and $\mathrm{N}$ concentrations and stocks in forest floor and top mineral soil layers.

\section{Material and methods}

The experimental area was located in Serra da Padrela, North Portugal at $41^{\circ} 29^{\prime} 24^{\prime \prime} \mathrm{N}$, $7^{\circ} 36^{\prime} 43^{\prime \prime}$ Wandanaltituderanging from 800 and 900 $\mathrm{m}$ (Figure 1). Mean annual temperature is $11.3^{\circ} \mathrm{C}$, with monthly averages ranging from $4.0^{\circ} \mathrm{C}$ (December) to $21.9^{\circ} \mathrm{C}$ (August) and a mean annual precipitation of $1381 \mathrm{~mm}$, with a typicaIly Mediterranean seasonal distribution (INMG 1991). Soils are classified as Orthi-Umbric Cambisols developed on schists (IUSS Working Group 2015), with medium-texture, acid $\mathrm{pH}$, very low $\mathrm{P}$, moderate to high $\mathrm{K}$ contents and moderate organic matter content (Agroconsultores and Coba 1991; Martins et al. 2007).

The study was carried out in four 60 year old forest stands. Two of the tree species are well represented in the northern region of the country, Castanea sativa Miller (CS) and Pinus pinaster Aiton (PP), and two, although with lower coverage, have silvicultural interest, Pseudotsuga menziesii (Mirb.) Franco (PM) and Pinus nigra Arnold (PN). After 40 years, the CS stand was subject to a clearcut. Forest management continued in coppice regime from then onwards. As the PP stand is close to a village, some people collected forest floor litter (pine cones and leaves) for use as household fuel. In the selected sampling areas, topography, lithology and climate were similar, therefore allowing comparisons on soil $\mathrm{C}$ and $\mathrm{N}$ stocks between the tree species. Dendrometric characteristics of the tree species are shown in Table 1. Although tree density, dominant height and mean diameter are clearly different in stands with similar age (PP, $\mathrm{PN}$ and $\mathrm{PM}$ ), characterizing these species stand at that age in such geographical setting, their basal area is around $50 \mathrm{~m}^{2} \mathrm{ha}^{-1}$, while for CS it is half of that value. Data for CS corresponds to the coppice-period, meaning that the dendrometric characteristics represent those of a younger stand in the same ecological conditions.

In each stand, 15 sampling sites were randomly established. In each one of these, the forest floor was collected in spring in a $0.49 \mathrm{~m}^{2}$ quadrat and divided, according to morphological criteria, into L-layer (Litter layer, composed by organic material recently fallen that is readily identifiable as 


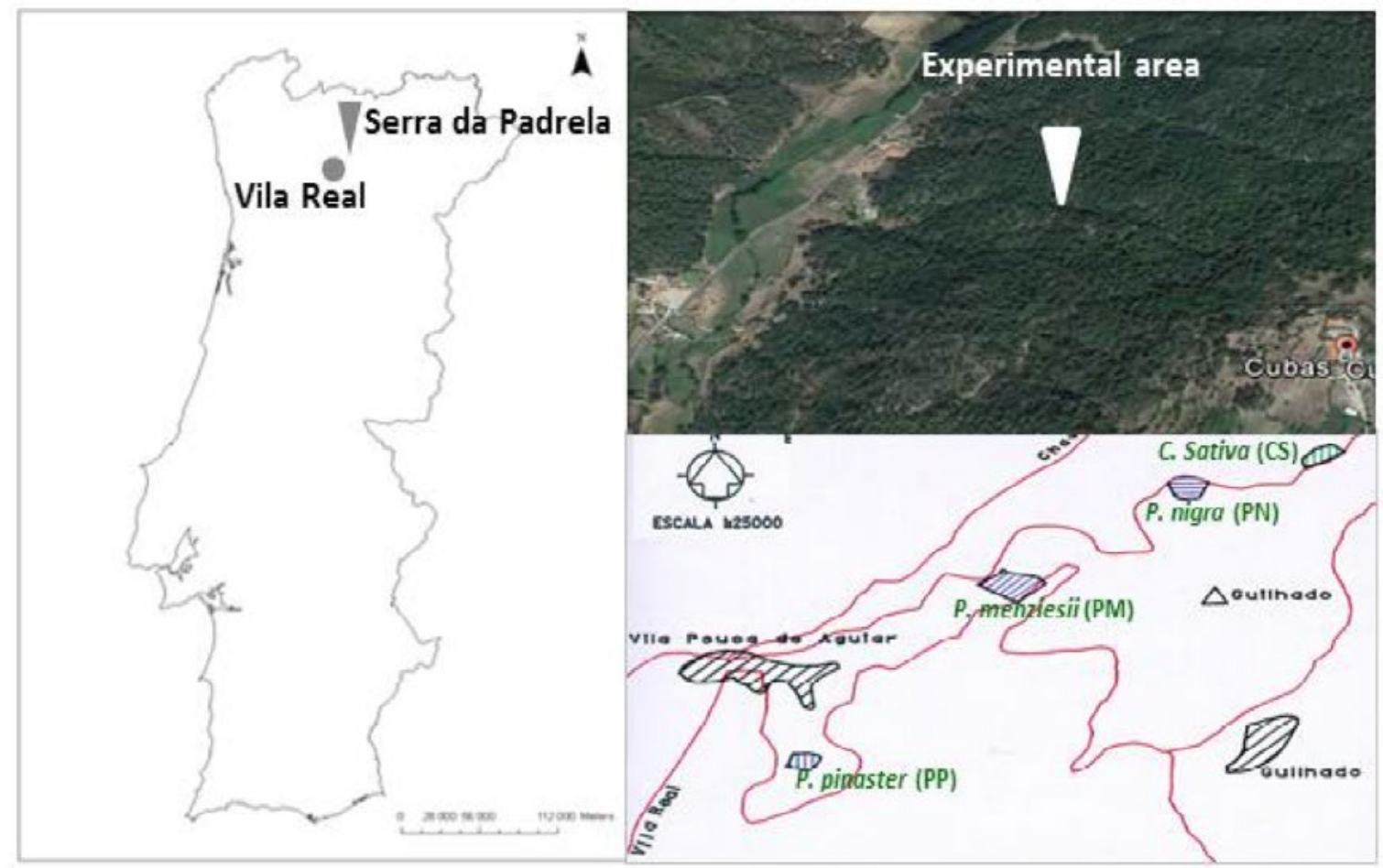

Figure 1. Location of the study area in Serra da Padrela, North of Portugal.

Table 1. Mean stand characteristics of the studied plots for Pinus pinaster (PP), Pinus nigra (PN), Pseudotsuga menziesii (PM) and Castanea sativa (CS)

\begin{tabular}{lccccc} 
Species & $\begin{array}{c}\text { Number of stems } \\
\left(\text { trees } \text { ha }^{-1}\right)\end{array}$ & $\begin{array}{c}\text { Age } \\
\text { (years) }\end{array}$ & $\begin{array}{c}\text { Dominant height } \\
(\mathrm{m})\end{array}$ & $\begin{array}{c}\text { Mean diameter } \\
(\mathrm{cm})\end{array}$ & $\begin{array}{c}\text { Basal area } \\
\left(\mathrm{m}^{2} \mathrm{ha}^{-1}\right)\end{array}$ \\
\hline PP & 988 & 58 & 16.2 & 25.4 & 49.1 \\
\hline PN & 475 & 59 & 22.8 & 34.3 & 43.9 \\
\hline PM & 313 & 59 & 34.8 & 46.8 & 53.3 \\
\hline CS $^{*}$ & 1438 & 57 & 13.3 & 14.7 & 24.6 \\
\hline
\end{tabular}

* For CS the characteristics correspond to the coppice period, 17 years old.

to origin), F-layer (Fermentation layer, comprised organic material partly decomposed, but yet recognizable as to origin) and $\mathrm{H}$-layer (Humus layer, comprised well-decomposed organic material in which plant structures are generally not recognizable, containing considerable amount of mineral matter) (Wesemael 1993; van Delft et al. 2006). The L-layer and F-layer were separated in leaves, pine cones/chestnut husks and branches. Then, samples of each component of the $\mathrm{L}$ and $\mathrm{F}$ layers were grouped three to three, making five samples per component of each layer, resulting in a total of 15 samples for the L-layer, 15 samples for the F-layer and five samples for the $\mathrm{H}$-layer. Forest floor samples were dried at $65^{\circ} \mathrm{C}$ for $72 \mathrm{~h}$ to determine dry mass. In the same 15 quadrats where the forest floor sampling was carried out, disturbed soil samples were collected in the depths $0-10$ and $10-20 \mathrm{~cm}$. Bulk density (BD) was measured at the same depths in undisturbed samples collected in $100 \mathrm{~cm}^{3}$ cylinders. Soil samples were collected on mineral topsoil $(0-20 \mathrm{~cm})$, as this is the relevant depth for spatial survey of $\mathrm{C}$ storage, according to the 
Kyoto Protocol requirements (Schulp et al. 2008; Vesterdal et al. 2008; Sil et al. 2017).

Soil samples were air dried and sieved to determine the coarse fraction $(>2 \mathrm{~mm}$ ). All forest floor and mineral soil samples were analyzed for total C by dry combustion (ISO 1995) and for total $\mathrm{N}$ by Kjeldahl method. Soil samples were tested with an acid-drop but no carbonates were detected, thus the total soil $\mathrm{C}$ was assumed to be comparable to soil organic $C$. Forest floor mass values were converted to $\mathrm{C}\left(\mathrm{Mg} \mathrm{ha}^{-1}\right)$ and $\mathrm{N}\left(\mathrm{kg} \mathrm{ha}^{-1}\right)$ multiplying these values by the $\mathrm{C}$ and $\mathrm{N}$ concentrations in dry matter. Soil organic $\mathrm{C}\left(\mathrm{Mg} \mathrm{ha}^{-1}\right)$ and total $\mathrm{N}$ in soil $\left(\mathrm{Mg} \mathrm{ha}^{-1}\right)$ were calculated multiplying $\mathrm{C}$ and $\mathrm{N}$ concentrations by bulk density and thickness of the mineral soil layer with a correction for the coarse element content. Statistical analysis of data comprised one-way ANOVA and multiple comparison of averages (Tukey, $5 \%$ ), performed to assess the significance of species effects on results.

\section{Results}

3.1. Forest floor mass and concentrations of $C$ and $\mathrm{N}$

According to the results expressed in Figure 2, the forest floor mass was significantly higher for PN (59.3 $\left.\mathrm{Mg} \mathrm{ha}^{-1}\right)$, followed by PM (33.0 Mg ha-1) and PP (23.5 Mg ha-1) and finally the CS species $\left(16.6 \mathrm{Mg} \mathrm{ha}^{-1}\right)$. Leaves were the main constituent of the forest floor in all species, but in PN the pine cones had an important mass (Table 2). The differences among species can be essentially related to the anthropogenic disturbances in PP (organic residues collection) and CS stands (clearcutting after 40 years), pine cones production (high for PN) and quality of organic material constituting the forest floor (Tables 2 and 3). Organic layer total mass increased from $L$ to $F$ and decreased to $\mathrm{H}$ (Table 2).

The organic components of the PM and CS tended to show higher concentrations of $\mathrm{N}$ and lower of $\mathrm{C}$, relative to $\mathrm{PP}$ and $\mathrm{PN}$, which was reflected in the C: $\mathrm{N}$ ratio and in the decomposition rate of the organic components (Table 3). The concentration of $\mathrm{N}$ tended to decrease from the leaves to the pine cones/chestnut husks and

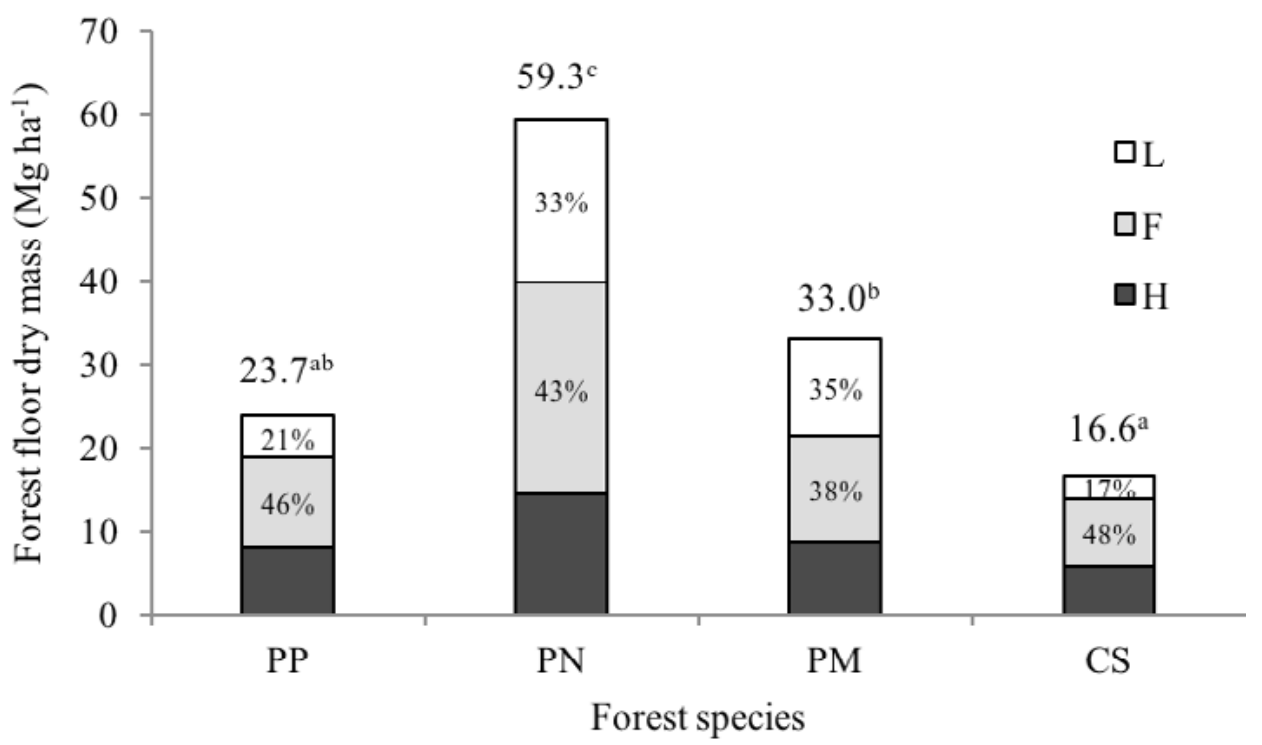

Figure 2. Total forest floor dry mass $\left(\mathrm{Mg} \mathrm{ha}^{-1}\right)$ of $\mathrm{L}, \mathrm{F}$ and $\mathrm{H}$ layers from species PP (Pinus pinaster), PN (Pinus nigra), $\mathrm{PM}$ (Pseudotsuga menziesii) and CS (Castanea sativa). Values followed by different letters are statistically different $(p<0.05)$ 
Table 2. Forest floor dry mass $\left(\mathrm{Mg} \mathrm{ha}^{-1}\right)$ of $\mathrm{L}, \mathrm{F}$ and $\mathrm{H}$ layers (mean \pm standard deviation). Leaves, pine cones/chestnut husks (pc/ch) and branches from species PP (Pinus pinaster), PN (Pinus nigra), PM (Pseudotsuga menziesii) and CS (Castanea sativa). For components or layers, values followed by different letters are statistically different $(p<0.05)$

\begin{tabular}{|c|c|c|c|c|c|}
\hline \multirow{2}{*}{ Species } & \multirow{2}{*}{$\begin{array}{l}\text { Forest floor } \\
\text { layers }\end{array}$} & \multicolumn{3}{|c|}{ Component } & \multirow{2}{*}{ Overall } \\
\hline & & leaves & $p c / c h$ & branches & \\
\hline \multirow[t]{4}{*}{ PP } & L & $3.5 \pm 1.8$ & $0.5 \pm 0.8$ & $0.9 \pm 0.7$ & $4.9 \pm 1.0^{a}$ \\
\hline & $\mathrm{F}$ & $9.9 \pm 2.7$ & $0.1 \pm 0.2$ & $0.9 \pm 0.9$ & $10.9 \pm 1.5^{b}$ \\
\hline & $\mathrm{H}$ & & & & $7.9 \pm 0.5^{b}$ \\
\hline & Overall & $13.4 \pm 2.3^{b}$ & $0.6 \pm 0.5^{a}$ & $1.8 \pm 0.8^{a}$ & \\
\hline \multirow[t]{4}{*}{ PN } & L & $3.6 \pm 1.3$ & $10.7 \pm 8.5$ & $5.3 \pm 7.8$ & $19.6 \pm 4.3^{b}$ \\
\hline & $\mathrm{F}$ & $17.1 \pm 4.1$ & $5.7 \pm 4.9$ & $2.6 \pm 2.5$ & $25.4 \pm 3.8^{b}$ \\
\hline & $\mathrm{H}$ & & & & $14.3 \pm 1.0^{\circ}$ \\
\hline & Overall & $20.7 \pm 2.6^{c}$ & $16.4 \pm 6.2^{b}$ & $7.9 \pm 3.9^{a}$ & \\
\hline \multirow[t]{4}{*}{ PM } & L & $4.6 \pm 3.3$ & $0.5 \pm 0.5$ & $6.6 \pm 3.8$ & $11.7 \pm 2.7^{a}$ \\
\hline & $\mathrm{F}$ & $12.0 \pm 5.1$ & $0.1 \pm 0.2$ & $0.6 \pm 0.6$ & $12.7 \pm 1.7^{a}$ \\
\hline & $\mathrm{H}$ & & & & $8.6 \pm 0.6^{a}$ \\
\hline & Overall & $16.6 \pm 3.2^{c}$ & $0.6 \pm 0.3^{a}$ & $7.2 \pm 1.8^{b}$ & \\
\hline \multirow[t]{4}{*}{ cs } & L & $2.0 \pm 1.0$ & $0.2 \pm 0.2$ & $0.7 \pm 0.4$ & $2.9 \pm 0.5^{a}$ \\
\hline & $\mathrm{F}$ & $7.2 \pm 2.4$ & $0.2 \pm 0.2$ & $0.6 \pm 0.4$ & $8.0 \pm 1.6^{b}$ \\
\hline & $\mathrm{H}$ & & & & $5.7 \pm 0.4^{b}$ \\
\hline & Overall & $9.2 \pm 1.3^{b}$ & $0.4 \pm 0.3^{\mathrm{a}}$ & $1.3 \pm 0.4^{\mathrm{a}}$ & \\
\hline
\end{tabular}

Table 3. Carbon and $\mathrm{N}$ concentrations and $\mathrm{C}: \mathrm{N}$ ratio of $\mathrm{L}, \mathrm{F}$ and $\mathrm{H}$ forest floor layers, expressed as mean and standard deviation. Leaves, pine cones/chestnut husks (pc/ch) and branches from species PP (Pinus pinaster), PN (Pinus nigra), PM (Pseudotsuga menziesii) and CS (Castanea sativa). For the same component, values followed by different letters in columns are statistically different $(p<0.05)$

\begin{tabular}{|c|c|c|c|c|c|c|c|}
\hline \multirow{3}{*}{ Species } & \multicolumn{7}{|c|}{ Forest floor layers } \\
\hline & \multicolumn{3}{|l|}{$L$} & \multicolumn{3}{|l|}{$F$} & \multirow[t]{2}{*}{$H$} \\
\hline & leaves & $\mathrm{pc} / \mathrm{ch}$ & branches & leaves & pc/ch & branches & \\
\hline \multicolumn{8}{|c|}{ C concentration $\left(\mathbf{g ~ k g}^{-1}\right)$} \\
\hline PP & $568 \pm 5^{b}$ & $574 \pm 3^{a}$ & $567 \pm 6^{a}$ & $447 \pm 22^{b}$ & $559 \pm 2^{a}$ & $563 \pm 7^{a}$ & $213 \pm 29^{a b}$ \\
\hline PN & $572 \pm 2^{b}$ & $576 \pm 2^{a}$ & $575 \pm 3^{a}$ & $459 \pm 67^{b}$ & $564 \pm 6^{a}$ & $566 \pm 6^{a}$ & $251 \pm 65^{b}$ \\
\hline PM & $526 \pm 15^{a}$ & $562 \pm 12^{a}$ & $571 \pm 3^{a}$ & $344 \pm 31^{a}$ & $541 \pm 20^{a}$ & $562 \pm 7^{a}$ & $129 \pm 49^{a}$ \\
\hline CS & $560 \pm 3^{b}$ & $554 \pm 38^{a}$ & $569 \pm 4^{a}$ & $365 \pm 23^{a}$ & $527 \pm 25^{a}$ & $554 \pm 5^{a}$ & $143 \pm 40^{\mathrm{a}}$ \\
\hline \multicolumn{8}{|c|}{$\mathbf{N}$ concentration $\left(\mathbf{g ~ k g}^{-1}\right)$} \\
\hline PP & $5.5 \pm 0.3^{a}$ & $7.6 \pm 3.7^{a b}$ & $5.6 \pm 3.3^{a b}$ & $14.0 \pm 4.8^{a}$ & $8.7 \pm 4.4^{a}$ & $5.4 \pm 0.4^{a}$ & $12.0 \pm 4.1^{a}$ \\
\hline PN & $7.9 \pm 4.4^{a}$ & $4.9 \pm 4.3^{a}$ & $3.3 \pm 0.5^{a}$ & $13.3 \pm 1.5^{a}$ & $5.4 \pm 0.7^{a}$ & $4.5 \pm 0.9^{a}$ & $14.5 \pm 3.2^{\mathrm{ab}}$ \\
\hline PM & $14.3 \pm 2.0^{b}$ & $5.3 \pm 1.5^{\mathrm{a}}$ & $4.9 \pm 0.5^{\mathrm{ab}}$ & $18.5 \pm 4.9^{\mathrm{ab}}$ & $7.5 \pm 6.4^{\mathrm{a}}$ & $6.3 \pm 1.9^{a}$ & $19.2 \pm 4.1^{\mathrm{ab}}$ \\
\hline CS & $15.1 \pm 0.6^{b}$ & $13.0 \pm 1.1^{b}$ & $8.6 \pm 2.0^{b}$ & $22.8 \pm 2.3^{b}$ & $16.7 \pm 1.1^{b}$ & $11.3 \pm 2.4^{b}$ & $22.8 \pm 6.7^{b}$ \\
\hline \multicolumn{8}{|l|}{$\mathrm{C}: \mathrm{N}$ ratio } \\
\hline PP & $94 \pm 7^{b}$ & $103 \pm 28^{b}$ & $118 \pm 46^{b}$ & $38 \pm 20^{b}$ & $49 \pm 31^{b}$ & $111 \pm 10^{b}$ & $18 \pm 4^{b}$ \\
\hline PN & $85 \pm 29^{b}$ & $168 \pm 72^{c}$ & $175 \pm 31^{c}$ & $34 \pm 3^{b}$ & $107 \pm 15^{c}$ & $132 \pm 28^{c}$ & $17 \pm 2^{b}$ \\
\hline PM & $38 \pm 6^{a}$ & $120 \pm 43^{b}$ & $117 \pm 13^{b}$ & $20 \pm 6^{a}$ & $42 \pm 2^{b}$ & $91 \pm 32^{b}$ & $7 \pm 2^{a}$ \\
\hline CS & $38 \pm 1^{a}$ & $53 \pm 14^{a}$ & $76 \pm 13^{a}$ & $16 \pm 2^{a}$ & $26 \pm 27^{a}$ & $49 \pm 13^{a}$ & $7 \pm 2^{a}$ \\
\hline
\end{tabular}


from these to the branches, showing an inverse trend for $\mathrm{C}$, but with some variations of this pattern in the L-layer. As expected, the C concentration decreased slightly from the L-layer to F-layer and more markedly to the H-layer, while $\mathrm{N}$ concentration increased. The decrease of $\mathrm{C}$ was more evident for leaves, since the $\mathrm{C}: \mathrm{N}$ ratio was lower for these components (Table 3). The increased $\mathrm{N}$ from the L-layer to $\mathrm{H}$-layer was related with the process of humification. The $\mathrm{C}: \mathrm{N}$ ratio varied between 143:1 (L-layer of PN) and 7:1 (H-layer of PM and CS). In the L and F layers the maximum was reached in branches of PN (175:1 and 132:1, respectively) and the minimum in leaves of CS (38:1 and 16:1, respectively) (Table 3; Figure 6).

\subsection{Carbon and nitrogen storage in forest floor}

The $\mathrm{C}$ storage was significantly higher in the $\mathrm{F}$ layer for PP and CS, with the other species (PN and PM) showing values similar to those of the L-layer. The H-layer was, in all species, the one with the lowest values. The amount of $\mathrm{N}$ stored follows a pattern slightly different from that recorded for $\mathrm{C}$ as the three organic layers differ significantly from each other in all species, following the sequence F-layer $>\mathrm{H}$-layer $>$ L-layer. For PP and CS approximately $70 \%$ of the $C$ was stored in leaves. In the PM and PN this value decreased to $54 \%$ and $36 \%$ respectively, with the pine cones representing a high percentage in the case of the PN (34\%) and the branches in the case of PM (33\%) (Table 4).

Table 4. Carbon $\left(\mathrm{Mg} \mathrm{ha}^{-1}\right)$ and $\mathrm{N}$ stocks $\left(\mathrm{Kg} \mathrm{ha}^{-1}\right)$ in $\mathrm{L}, \mathrm{F}$ and $\mathrm{H}$ forest floor layers, expressed as mean and standard deviation. Leaves, pine cones/chestnut husks (pc/ch) and branches from species PP (Pinus pinaster), PN (Pinus nigra) PM (Pseudotsuga menziesii) and CS (Castanea sativa). For components or layers, values followed by different letters are statistically different $(p<0.05)$

\begin{tabular}{|c|c|c|c|c|c|c|c|c|c|}
\hline \multirow[t]{2}{*}{ Species } & \multirow[t]{2}{*}{ Layer } & \multicolumn{3}{|c|}{ Component } & \multirow[t]{2}{*}{ Overall } & \multicolumn{3}{|l|}{ Component } & \multirow[t]{2}{*}{ Overall } \\
\hline & & leaves & $p c / c h$ & branches & & leaves & $p c / c h$ & branches & \\
\hline & & \multicolumn{3}{|c|}{ C storage $\left(\mathrm{Mg} \mathrm{ha}^{-1}\right)$} & & \multicolumn{3}{|c|}{$\mathbf{N}$ storage $\left(\mathbf{k g ~ h a} \mathbf{~}^{-1}\right)$} & \\
\hline \multirow[t]{4}{*}{ PP } & L & $2.0 \pm 1.0$ & $0.3 \pm 0.5$ & $0.5 \pm 0.4$ & $2.8 \pm 0.5^{a}$ & $19.0 \pm 6.0$ & $3.0 \pm 3.2$ & $3.8 \pm 1.3$ & $25.8 \pm 3.2^{\mathrm{a}}$ \\
\hline & $\mathrm{F}$ & $4.6 \pm 1.1$ & $0.1 \pm 0.1$ & $0.5 \pm 0.5$ & $5.2 \pm 0.6^{b}$ & $142.7 \pm 50.2$ & $1.7 \pm 1,9$ & $4.9 \pm 2.4$ & $149.3 \pm 16.1^{c}$ \\
\hline & $\mathrm{H}$ & & & & $1.8 \pm 0.3^{a}$ & & & & $107.0 \pm 1.2^{b}$ \\
\hline & Overall & $6.6 \pm 1.0^{b}$ & $0.4 \pm 0.4^{a}$ & $1.0 \pm 0.5^{a}$ & & $161.7 \pm 33.8^{b}$ & $4.7 \pm 2.6^{a}$ & $8.7 \pm 1.5^{a}$ & \\
\hline \multirow[t]{4}{*}{ PN } & L & $2.0 \pm 0.7$ & $6.2 \pm 4.9$ & $3.0 \pm 4.5$ & $11.2 \pm 3.2^{\mathrm{b}}$ & $28.3 \pm 16.2$ & $57.9 \pm 64.2$ & $16.0 \pm 14.3$ & $102.2 \pm 28.1^{a}$ \\
\hline & $\mathrm{F}$ & $7.8 \pm 2.2$ & $3.2 \pm 2.8$ & $1.4 \pm 1.4$ & $12.4 \pm 1.8^{b}$ & $228.9 \pm 47.3$ & $29.9 \pm 8.3$ & $11.0 \pm 3.0$ & $269.8 \pm 9.7^{c}$ \\
\hline & $\mathrm{H}$ & & & & $3.7 \pm 0.9^{a}$ & & & & $212.9 \pm 15.7^{b}$ \\
\hline & Overall & $9.8 \pm 1.7^{\mathrm{b}}$ & $9.4 \pm 3.3^{b}$ & $4.4 \pm 2.9^{a}$ & & $257.2 \pm 39.1^{\mathrm{c}}$ & $87.8 \pm 10.7^{b}$ & $27.0 \pm 5.3^{\mathrm{a}}$ & \\
\hline \multirow[t]{4}{*}{ PM } & $\mathrm{L}$ & $2.4 \pm 1.8$ & $0.3 \pm 0.3$ & $3.8 \pm 2.2$ & $6.5 \pm 1.1^{\mathrm{b}}$ & $65.0 \pm 22.6$ & $2.8 \pm 1.4$ & $32.4 \pm 14.8$ & $100.2 \pm 13.9^{a}$ \\
\hline & $\mathrm{F}$ & $4.2 \pm 1.9$ & $0.1 \pm 0.2$ & $0.3 \pm 0.3$ & $4.6 \pm 0.5^{b}$ & $230.0 \pm 85.7$ & $3.3 \pm 1.7$ & $3.9 \pm 2.4$ & $237.2 \pm 10.3^{c}$ \\
\hline & $\mathrm{H}$ & & & & $1.2 \pm 0.4^{\mathrm{a}}$ & & & & $167.7 \pm 7.5^{b}$ \\
\hline & Overall & $6.6 \pm 1.2^{b}$ & $0.4 \pm 0.2^{\mathrm{a}}$ & $4.1 \pm 1.3^{b}$ & & $295.0 \pm 66.4^{c}$ & $6.1 \pm 1.5^{\mathrm{a}}$ & $36.3 \pm 6.2^{b}$ & \\
\hline \multirow[t]{4}{*}{ cs } & L & $1.1 \pm 0.5$ & $0.1 \pm 0.1$ & $0.4 \pm 0.7$ & $1.6 \pm 0.4^{\mathrm{b}}$ & $30.1 \pm 9.3$ & $2.9 \pm 1.7$ & $5.2 \pm 3.8$ & $38.2 \pm 2.9^{a}$ \\
\hline & $\mathrm{F}$ & $2.7 \pm 1.0$ & $0.1 \pm 0.1$ & $0.3 \pm 0.2$ & $3.1 \pm 0.2^{\mathrm{c}}$ & $166.4 \pm 57.0$ & $3.4 \pm 3.0$ & $6.4 \pm 1.0$ & $176.2 \pm 13.4^{c}$ \\
\hline & $\mathrm{H}$ & & & & $0.8 \pm 0.2^{\mathrm{a}}$ & & & & $131.0 \pm 7.5^{b}$ \\
\hline & Overall & $3.8 \pm 0.9^{b}$ & $0.2 \pm 0.1^{a}$ & $0.7 \pm 0.5^{a}$ & & $196.5 \pm 42.1^{b}$ & $6.3 \pm 3.2^{a}$ & $11.6 \pm 2.9^{a}$ & \\
\hline
\end{tabular}

Total forest floor $\mathrm{C}$ and $\mathrm{N}$ stocks varied significantly among species. The PN had the largest forest floor $\mathrm{C}$ stocks $\left(27.3 \mathrm{Mg} \mathrm{ha}^{-1}\right)$, significantly different from the other three species (Figure 3). For this species, the C stored in leaves (9.8 $\left.\mathrm{Mg} \mathrm{ha}^{-1}\right)$, pine cones (9.4 Mg ha $\mathrm{Mg}^{-1}$ ) and branches (4.4 $\mathrm{Mg} \mathrm{ha}^{-1}$ ) of the $\mathrm{L}$ and $\mathrm{F}$ layer, presents more equitable proportions than the remaining ones. In contrast, a significantly lower amount of $\mathrm{C}$ is 
stored in the forest floor of CS (5.5 Mg ha-1), with the leaves storing $3.8 \mathrm{Mg} \mathrm{ha}^{-1}$, meaning about $70 \%$ of the total C stocks (Table 4). A similar pattern was found for $\mathrm{N}$, as the highest amounts of $\mathrm{N}$ stored were recorded for $\mathrm{PN}$ $\left(5.8 \mathrm{~kg} \mathrm{ha}^{-1}\right)$ and PM (5.1 kg ha-1), whereas PP
(2.9 kg ha-1) and CS (3.5 kg ha-1) had significantly lower amounts. In general, the leaf component represented more than $50 \%$ of the $\mathrm{N}$ stored in the $L$ and $F$ layers of the forest floor (Table 4, Figure 3).

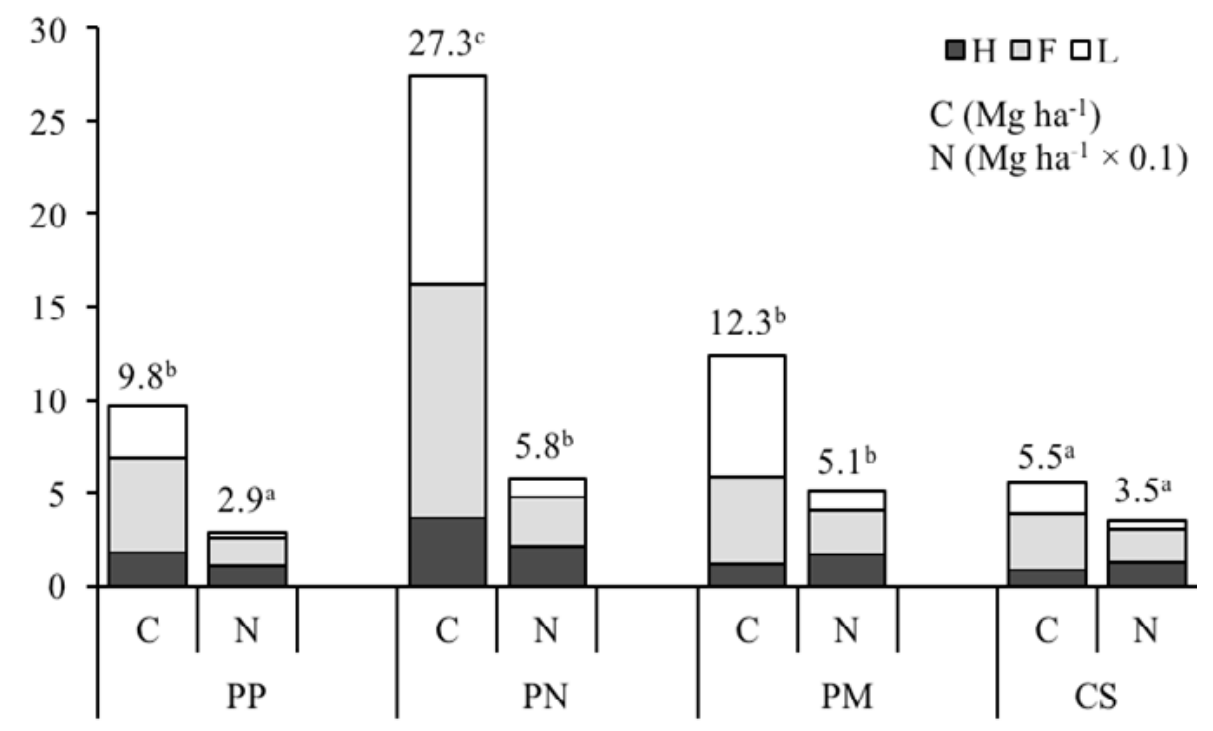

Figure 3. Carbon and $\mathrm{N}$ stocks of $\mathrm{L}, \mathrm{F}$ and $\mathrm{H}$ forest floor layers from species PP (Pinus pinaster), PN (Pinus nigra), PM (Pseudotsuga menziesii) and CS (Castanea sativa). For C or N, values followed by different letters are statistically different $(p<0.05)$.

Table 5. Carbon and $\mathrm{N}$ concentration $\left(\mathrm{g} \mathrm{kg}^{-1}\right)$, soil bulk density $\left(\mathrm{g} \mathrm{cm}^{-3}\right)$ and coarse element content (\%) in mineral soil layers for species PP (Pinus pinaster), PN (Pinus nigra), PM (Pseudotsuga menziesii) and CS (Castanea sativa), expressed as mean and standard deviation. Different letters in the rows indicate significant differences among species $(p<0.05)$

\begin{tabular}{|c|c|c|c|c|}
\hline \multirow{2}{*}{ Depth (cm) } & \multicolumn{4}{|l|}{ Species } \\
\hline & PP & PN & PM & CS \\
\hline \multicolumn{5}{|c|}{ SOC concentration $\left(\mathrm{g} \mathrm{kg}^{-1}\right)$} \\
\hline $0-10$ & $21.0 \pm 12.9 a$ & $40.8 \pm 3.0 b$ & $33,1 \pm 3.0 \mathrm{ab}$ & $38.0 \pm 7.0 \mathrm{ab}$ \\
\hline $10-20$ & $14.6 \pm 9.5 a$ & $34.5 \pm 6.8 a b$ & $28.9 \pm 3.3 a b$ & $35.2 \pm 7.8 b$ \\
\hline \multicolumn{5}{|c|}{ Total $\mathbf{N}$ concentration $\left(\mathbf{g ~ k g}^{-1}\right)$} \\
\hline $0-10$ & $1.5 \pm 1.0 a$ & $2.9 \pm 0.3 a b$ & $2.9 \pm 0.6 a b$ & $3.4 \pm 0.8 b$ \\
\hline $10-20$ & $1.1 \pm 1.0 a$ & $2.0 \pm 0.4 a b$ & $2.7 \pm 0.6 b$ & $3.0 \pm 0.3 b$ \\
\hline \multicolumn{5}{|c|}{ Bulk density $\left(\mathrm{g} \mathrm{cm}^{-3}\right)$} \\
\hline $0-10$ & $1.13 \pm 0.03 a$ & $0.98 \pm 0.01 a$ & $1.03 \pm 0.06 a$ & $0.96 \pm 0.03 a$ \\
\hline $10-20$ & $1.16 \pm 0.02 a$ & $1.07 \pm 0.03 a$ & $1.08 \pm 0.03 a$ & $1.02 \pm 0.03 a$ \\
\hline \multicolumn{5}{|c|}{ Coarse element content (\%) } \\
\hline $0-10$ & $42.8 \pm 6.1 a$ & $32,1 \pm 4.5 a$ & $35,4 \pm 5.3 a$ & $34.1 \pm 3.2 a$ \\
\hline $10-20$ & $40.5 \pm 5.6 a$ & $33.2 \pm 2.9 a$ & $40.8 \pm 5.1 \mathrm{a}$ & $44.1 \pm 4,3 a$ \\
\hline
\end{tabular}

SOC: soil organic carbon 


\subsection{Carbon and nitrogen storage in mineral soil}

The $\mathrm{C}$ and $\mathrm{N}$ concentrations in soils decreased with increasing depth in all species, showing values below $41 \mathrm{~g} \mathrm{~kg}^{-1}$ for $\mathrm{C}$ and $3.5 \mathrm{~g} \mathrm{~kg}^{-1}$ for N. Overall, PP and CS showed the lowest and highest values, respectively (Table 5). In the soil surface layer $(0-10 \mathrm{~cm}) \mathrm{C}$ concentration ranged from $40.8 \mathrm{~g} \mathrm{~kg}^{-1}$ (PN) to $21.0 \mathrm{~g} \mathrm{~kg}^{-1}$ (PP) and $\mathrm{N}$ concentration ranged from $3.4 \mathrm{~g} \mathrm{~kg}^{-1}$ (CS) to $1.5 \mathrm{~g} \mathrm{~kg}^{-1}$ (PP), in both cases revealing significant differences. Soil coarse elements content and bulk density do not differ between species, showing PP the highest values for both variables (Table 5).
The $0-20 \mathrm{~cm}$ soil depth contained a total of 64.6 58.3, 52.1 and $30.3 \mathrm{Mg} \mathrm{ha}^{-1}$ of $\mathrm{C}$ in the $\mathrm{PN}$, CS, PM and PP, respectively (Figure 4). The $\mathrm{N}$ stocks followed the sequence CS $\left(5.1 \mathrm{Mg} \mathrm{ha}^{-1}\right)>$ PM (4.6 Mg ha-1) > PN (4.2 Mg ha-1) > PP (2.2 Mg ha-1) (Figure 5). The distribution of C and $\mathrm{N}$ in the two soil layers $(0-10$ and $10-20 \mathrm{~cm})$ is quite similar, presenting a slightly higher amount in the uppermost soil layer (slightly above $50 \%$ ) (Figures 4 and 5). Soil C: $\mathrm{N}$ ratio range from 11:1 (CS, PM) to 17:1 (PN). As expected, the $\mathrm{C}: \mathrm{N}$ ratio drops considerably from the $\mathrm{L}$ and $\mathrm{F}$ layers to the $\mathrm{H}$ layer and the mineral soil layers (Figure 6).

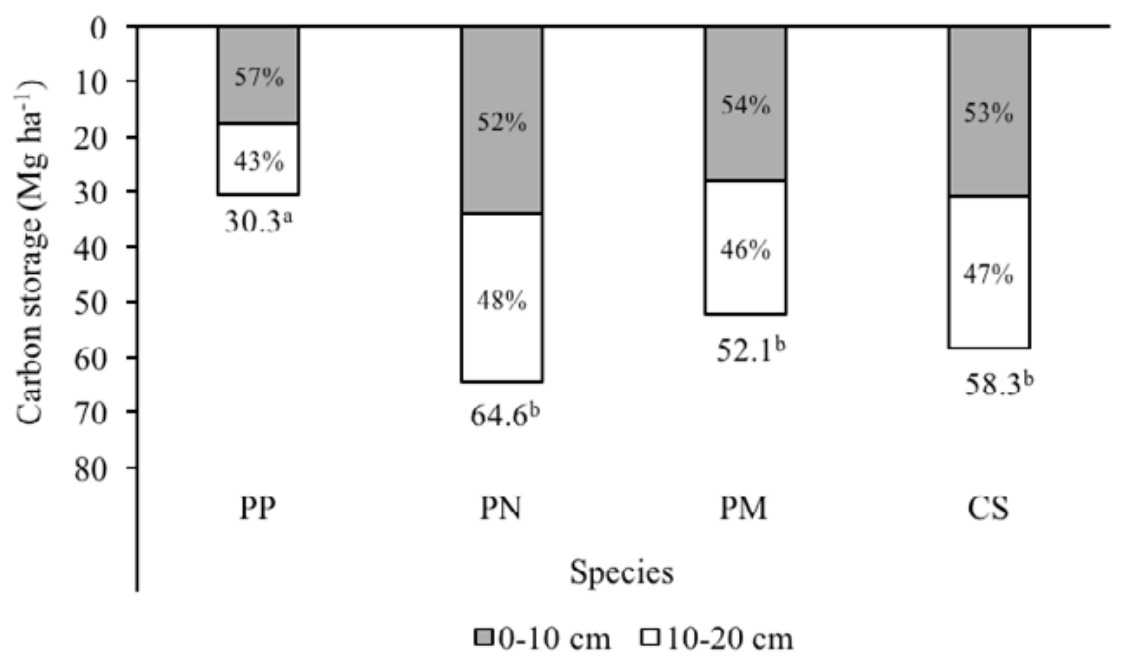

Figure 4. Total soil C storage from species PP (Pinus pinaster), PN (Pinus nigra), PM (Pseudotsuga menziesii) and CS (Castanea sativa). Values followed by different letters are statistically different $(p<0.05)$.

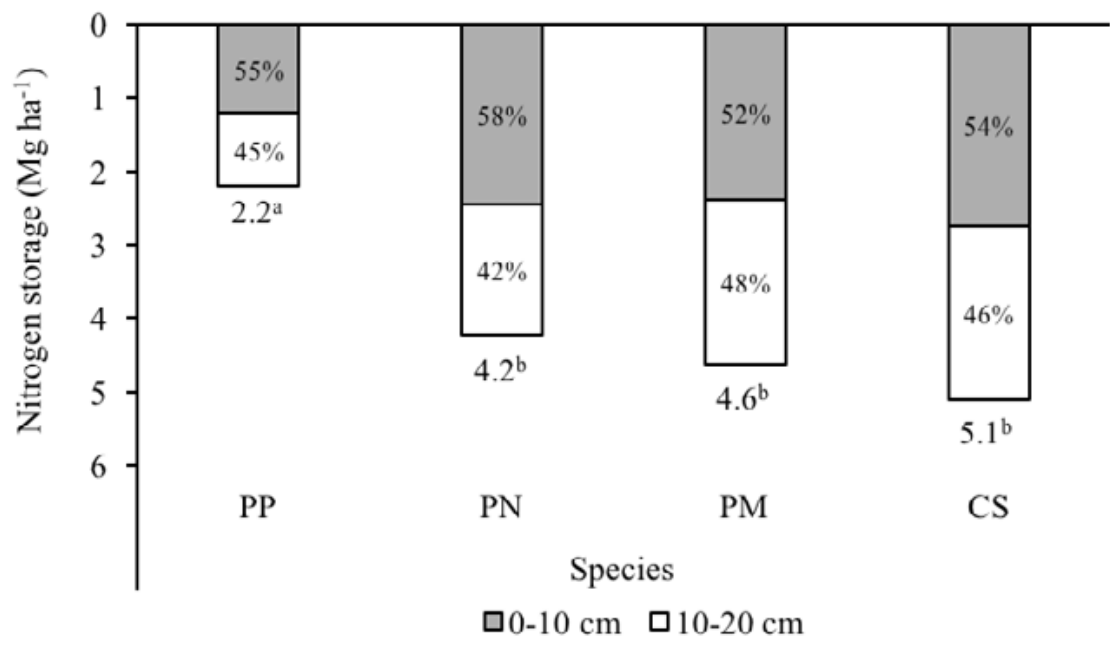

Figure 5. Total soil N storage from species PP (Pinus pinaster), PN (Pinus nigra), PM (Pseudotsuga menziesii) and CS (Castanea sativa). Values followed by different letters are statistically different $(p<0.05)$. 


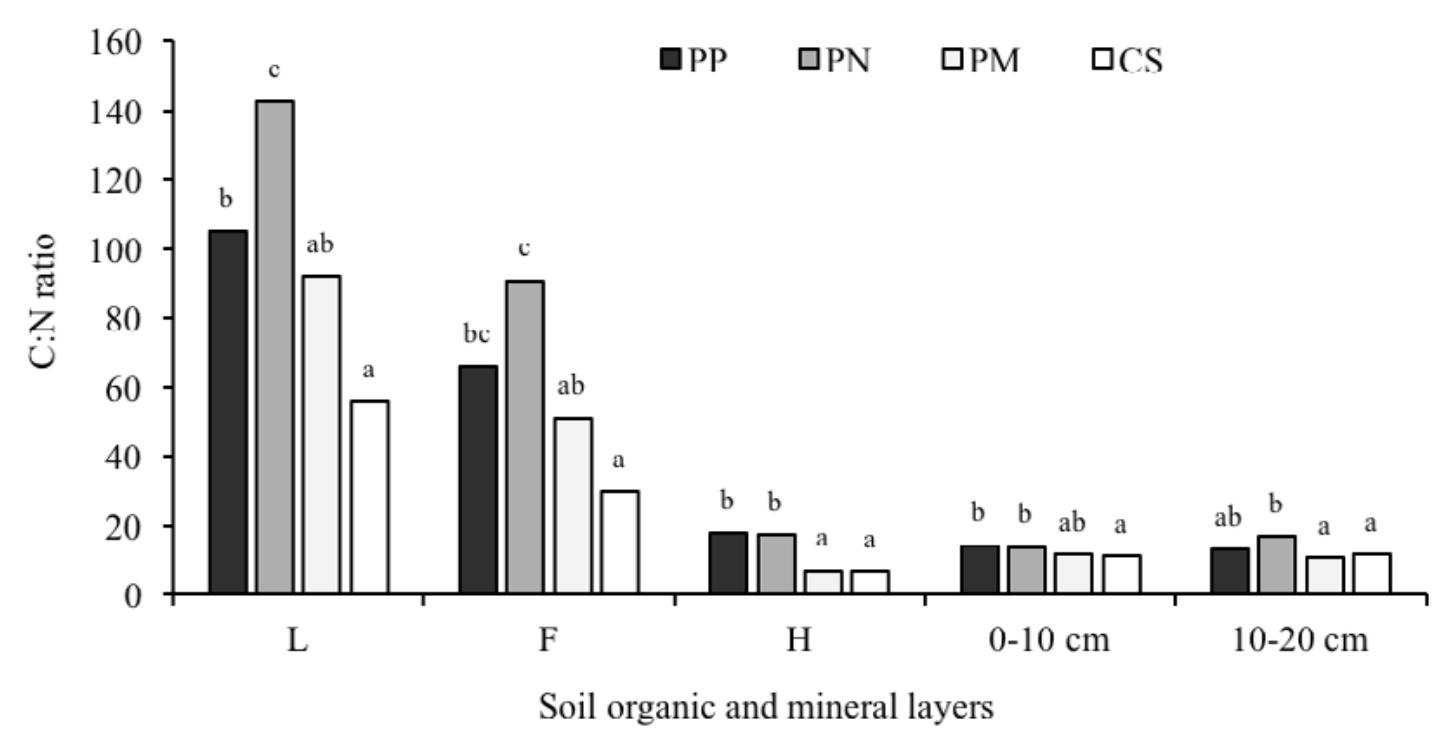

Figure 6. The $\mathrm{C}: \mathrm{N}$ ratio of $\mathrm{L}, \mathrm{F}$ and $\mathrm{H}$ forest floor layers and soil mineral layers $(0-10$ and $10-20 \mathrm{~cm})$ from species PP (Pinus pinaster), PN (Pinus nigra), PM (Pseudotsuga menziesii) and CS (Castanea sativa). For each layer, values followed by different letters are statistically different $(p<0.05)$.

3.4. Total carbon and nitrogen storage in forest floor and mineral soil

After 60 years the effect of forest species and management practices on $\mathrm{C}$ and $\mathrm{N}$ storage was visible both in the forest floor and the mineral soil (Figure 7). Total C storage was significantly higher in PN (92.1 Mg ha-1) and significantly lower in PP (40.0 Mg ha ${ }^{-1}$ ), the two remainder species showing intermediate values, practically identical (64.4 $\mathrm{Mg} \mathrm{ha}^{-1}$ for PM and 63.9 $\mathrm{Mg} \mathrm{ha}^{-1}$ for CS). Overall, the forest floor in CS contained less $\mathrm{C}$ and $\mathrm{N}$ than forest floor in conifer stands (PP, PN and PM), but the mineral soil of the deciduous tree species (CS) recorded amounts of $N$ higher than in the three evergreen species and C stocks very similar to PN, the forest species with the highest amount of $\mathrm{C}$ in the mineral soil. The soil was the largest $\mathrm{C}$ and $\mathrm{N}$ pool representing percent values that ranged from 70 (PN) to 91 (CS) for $\mathrm{C}$ and from 88 (PP and PN) to 94 (CS) for $\mathrm{N}$ (Figure 7).

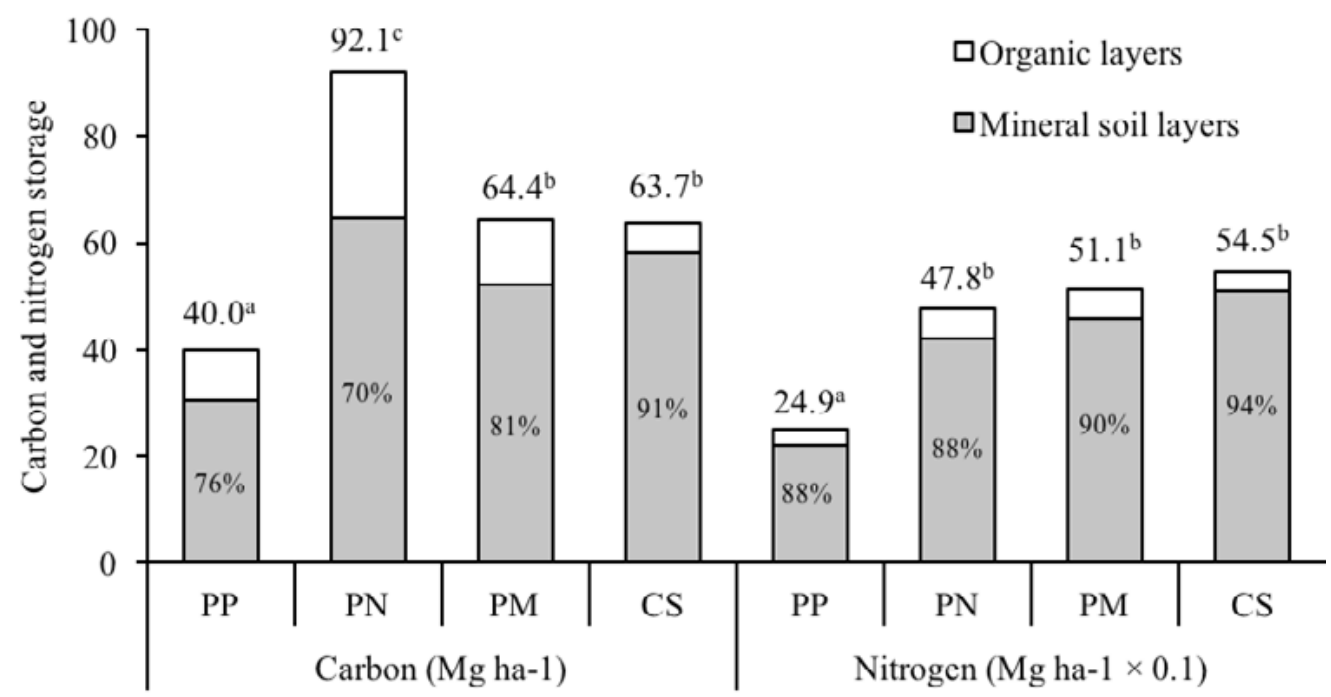

Figure 7. Total $\mathrm{C}$ and $\mathrm{N}$ stored in soil organic and mineral layers from species PP (Pinus pinaster), PN (Pinus nigra), PM (Pseudotsuga menziesii) and CS (Castanea sativa). For $\mathrm{C}$ or $\mathrm{N}$, values followed by different letters are statistically different $(p<0.05)$. 


\section{Discussion}

The overall forest floor mass in conifer stands (PP, PN and PM) was higher in all organic layers $(\mathrm{L}, \mathrm{F}$ and $\mathrm{H})$ than in broadleaf stands (CS). Under the coniferous species there was a huge quantity of organic materials poorly decomposed, while under broadleaved species (CS) there was the biggest transformation of forest floor and incorporation in mineral soil, because litter chemistry was a determinant factor controlling the decomposition process (Hobbie 1996; Shaw and Harte 2001; Mueller et al. 2012; Guendehou et al. 2014; Kooch et al. 2017). These observations were in accordance of decomposition litter study conducted in these stands, which recorded annual losses of 15.3 , $18.3,29.7$ and $41.7 \%$ for PN, PP, PM and CS, respectively (unpublished data). Identical results were reported by other authors (Rapp 1984; Schulp et al. 2008; Fonseca and Figueiredo 2010; Bargali et al. 2015). The lowest value found beneath the CS stand could be explained by the highest decomposition rate associated with a lower C: $\mathrm{N}$ ratio of the forest floor layers (Thomsen et al. 2008; Trum et al. 2011; Guendehou et al. 2014; Cools et al. 2014). Secondly, this stand was clearcut after 40 years, which had important consequences at soil level, namely alteration in the quantity and quality of biomass production, modification of the spontaneous vegetation and of microbial community composition (Merzouki et al. 1989; Prescott and Grayston 2013; Bargali et al. 2015). In addition, the export of plant material modifies the microclimatic and pedoclimatic conditions and the gains by the soil of organic material, resulting in a greater mineralization of the organic residues deposited on the soil surface. The clearcut was followed by a coppice regime, which implied the export of young plant material, rich in mineral components, and might result in the reduction of soil fertility in long term. The low forest floor mass of the PP species is explained by the litter transferred (leaves and pine cones) for domestic fuel and by the lower density of canopy per hectare. The values of PN and PM are mainly explained by size of leaves, being the main difference between these two species in pine cones production (very high for the PN) and in the decomposition rate (highest for PM).
Forest floor quality differs among species, with the highest $\mathrm{N}$ concentration and lowest organic $\mathrm{C}$ under $\mathrm{CS}$ species. The $\mathrm{C}$ concentration and $\mathrm{C}: \mathrm{N}$ ratio decreased from the $\mathrm{L}$ to the $\mathrm{H}$ layer and the $\mathrm{N}$ concentration reached its maximum in H-Layer, which is in agreement with other authors (Trum et al. 2011; Cools et al. 2014). The decrease of $C$ concentration is associated with the increase of the humification degree (Wardle 1993), with the mineral matter addition by biological activity and with the high porosity of the organic layers that allow fast exchanges with the atmosphere (Fernández et al. 1993). This reduction was more evident for leaves, with a higher decomposition rate and lower $\mathrm{C}: \mathrm{N}$ ratio (Yamashita et al. 2006). Forest floor C:N ratio under CS was the lowest and comparable with PM. Cremer et al. (2016) reported similar results when compared Pseudotsuga menziesii and Fagus sylvatica species. According to Kaspari et al. (2008), the decomposition process is affected by the initial $\mathrm{N}$ and $\mathrm{P}$ concentrations and the C:N ratio of litter. The C:N ratio decreased with decomposition, that is, from L-layer to H-layer (Cools et al. 2014). The evolution of the $\mathrm{C}$ concentration in the organic layers was similar between coniferous and broadleaved species, which is in agreement with other studies (e.g. Fernández et al. 1993; Trum et al. 2011). The increase in $N$ concentration during decomposition (from $\mathrm{L}$ to $\mathrm{H}$ layers) is a generally occurring phenomenon (Polglase et al. 1992; Shaw and Harte 2001; Trum et al. 2011; Bargali et al. 2015). Morphological and chemical characteristics of the organic residues may explain the highest $\mathrm{N}$ concentrations observed in CS (Fyles et al. 1991). Nitrogen deficiencies are frequent in coniferous stands where this element is immobilized in the organic layers accumulated on the surface soil. In these stands, residue accumulation is favored (Mahendrappa et al. 1986), due to litter quality produced, which in turn affects the decomposition rate and chemical elements release to the soil (Martins 2009). In summary, $\mathrm{C}$ and $\mathrm{N}$ concentrations in the forest floor layers were related to the nature of the forest species that affect the decomposition rate and the turnover of these elements in the soil (Martins et al. 2009; Fonseca et al. 2012; Kooch et al. 2017).

The $\mathrm{C}$ and $\mathrm{N}$ storage differs in forest floor and top mineral soil $(0-20 \mathrm{~cm})$ under different tree species 
(e.g. Alban 1982; Reich et al. 2005; Díaz-Pinés et al. 2011; Trum et al. 2011; Kooch et al. 2017). The $\mathrm{C}$ and $\mathrm{N}$ stocks in the forest floor highlight the effect of the human disturbances that occurred in the PP and CS stands and the combined effects of the quantity and quality biomass produced by different species (Alban 1982; Thomsen et al. 2008; Fonseca and Figueiredo 2012). This may have contributed to the lower values found for these species (PP and CS). In forest floor, C stocks were higher under conifer species (PN, 27.3 Mg ha-1 > PM, 12.3 Mg ha-1; PP, 9.8 $\mathrm{Mg} \mathrm{ha}^{-1}>\mathrm{CS}, 5.5 \mathrm{Mg} \mathrm{ha}^{-1}$ ) and $\mathrm{N}$ stocks showed a slightly different behavior (PN, 5.8 $\mathrm{Mg} \mathrm{ha}^{-1}$; $\mathrm{PM}, 5.1 \mathrm{Mg} \mathrm{ha}^{-1}>\mathrm{CS}, 3.5 \mathrm{Mg} \mathrm{ha}^{-1}$; $\mathrm{PP}$, $\left.2.9 \mathrm{Mg} \mathrm{ha}^{-1}\right)$. Overall, $\mathrm{N}$ storage was more representative in the $\mathrm{F}$-layer, $\mathrm{C}$ storage was quite similar in the $L$ and $F$ layers, especially in PN and PM species. Herrero et al. (2016) reported similar results for $C$ stocks in forest floor, with higher values in Pinus spp. (13.6 $\mathrm{Mg} \mathrm{ha}^{-1}$ ) than in Quercus pyrenaica $\left(5.4 \mathrm{Mg} \mathrm{ha}^{-1}\right)$. Average soil C stocks $(0-20 \mathrm{~cm})$ were lower under PP (30.3 $\left.\mathrm{Mg} \mathrm{ha}^{-1}\right)$ than PN (64.6 Mg ha-11), PM (52.1 Mg ha ${ }^{-1}$ ) and CS (58.3 Mg ha-1), with significant differences between the first and the former species. Trends in soil $\mathrm{N}$ stocks were comparable to those referred to $C$ stocks. Soil C stocks under PP stand were lower than those found by Nunes et al. (2010) until $30 \mathrm{~cm}$ of depth in soils developed beneath the same species in NW Portugal, where the values varied from 90.2 to $123.9 \mathrm{Mg} \mathrm{ha}^{-1}$. As stressed before, the human disturbances in the PP stand considerably affected the contents of $\mathrm{C}$ and $\mathrm{N}$ both in the forest floor and mineral soil. Several studies that focused on the species effects on mineral soil $C$ pool found no significant influence; nevertheless occasionally there was a tendency of more $\mathrm{C}$ in soils developed under some broadleaved species when compared with conifers (Oostra et al. 2006; Vesterdal et al. $2008,2013)$. A similar trend was also observed for CS (broadleaved species) in this study. Usually, the species with low $\mathrm{C}$ stocks on the forest floor tend to have more $C$ in the mineral soil (Vesterdal et al. 2013), however only CS species showed this trend. The $\mathrm{C}: \mathrm{N}$ ratio in soil depths $0-10$ and $10-20 \mathrm{~cm}$ was variable beneath the four species (PP, PN, PM and CS), which is seemingly associated with litter quality (Neirynck et al. 2000; Cools et al. 2014), besides other factors influencing the soil $\mathrm{C}: \mathrm{N}$ ratio such as management practices (Zhang et al. 2016), soil properties (Yamashita et al. 2006; Cools et al. 2014), forest species (e.g. Fonseca et al. 2012; Vesterdal et al. 2013; Cools et al. 2014; Zhang et al. 2016) and climate (Fonseca and Figueiredo 2012; Marty et al. 2017). The C:N ratio reflects the stability of soil organic matter and relative decomposition stage (Thomsen et al. 2008). Accordingly, the soil $\mathrm{C}$ and $\mathrm{N}$ stability was higher in $\mathrm{PN}$ and PP stands (higher values of $\mathrm{C}: \mathrm{N}$ ratio) and smaller in CS and PM stands (lower values of $\mathrm{C}: \mathrm{N}$ ratio).

Total $\mathrm{C}$ and $\mathrm{N}$ stored in soil horizons (forest floor + mineral soil) were affected by species (e. g. Reich et al. 2005; Díaz-Pinés et al. 2011; Fonseca et al. 2012; Gurmesa et al. 2013). The $\mathrm{PN}$ stand presented the largest amount of $\mathrm{C}$ (92.1 $\left.\mathrm{Mg} \mathrm{ha}^{-1}\right)$ and CS stand of $\mathrm{N}\left(54.5 \mathrm{Mg} \mathrm{ha}^{-1}\right)$. The mineral soil top layer was the major $\mathrm{C}$ and $\mathrm{N}$ pool in all species, representing above $70 \%$ for $\mathrm{C}$ and exceeding $88 \%$ for N. Despite its minor contribution to $\mathrm{C}$ and $\mathrm{N}$ stocks, the forest floor is an important component of the $\mathrm{C}$ and $\mathrm{N}$ biogeochemical cycles (Ordóñez et al. 2008), as it is the boundary between vegetation and soil.

\section{Conclusions}

Sixty years after installation of the stands, C and $\mathrm{N}$ concentrations and stocks in both forest floor and mineral soil are visibly different in areas covered with different forest species, under similar topographic, lithologic and climatic conditions. The $\mathrm{H}$-layer showed the highest concentrations in $\mathrm{N}$ and the lowest in $\mathrm{C}$, leaves in the $L$ and $F$ layers being the component with higher concentrations in both cases. On the other hand, the F-layer provides the larger contribution for $\mathrm{C}$ and $\mathrm{N}$ storage and $\mathrm{N}$, and, as also found in the $\mathrm{H}$ layer, leaves were the main pool of these elements. In general, the conifer species (PP, PN and PM) showed higher $\mathrm{C}$ and $\mathrm{N}$ stocks in the forest floor layers compared to the broadleaved species (CS). Stocks of $\mathrm{C}$ and $\mathrm{N}$ in the topsoil $(0-20 \mathrm{~cm})$ were lower in PP species than in other species (PN, PM and CS, all with similar values). 
Total C storage (forest floor + mineral soil till $20 \mathrm{~cm}$ depth) was higher in PN, intermediate in PM and CS and lower in PP. In contrast, $\mathrm{N}$ storage was similar in CS, PM, PN, and significantly lower in PP. Mineral soil had a major contribution to $\mathrm{C}$ and $\mathrm{N}$ storage, representing more than $70 \%$ and $88 \%$ of the totals stored down to $20 \mathrm{~cm}$ soil depth, respectively. Scientifically grounded improvements on current knowledge about forest species effects in $\mathrm{C}$ and $\mathrm{N}$ storage can be very important for decision-making on species selection for stand installation; in view of ecosystem services provision by forest areas.

\section{REFERENCES}

- Agroconsultores e Coba. 1991. Carta dos Solos do Nordeste de Portugal. Vila Real: PDRITM, UTAD.

- Alban DH. 1982. Effects of nutrient accumulation by aspen, spruce, and pine on soil properties. Soil Sci Soc Am J. 46:853-861.

- Bargali SS, Shukla K, Singh L, Grosh L, Lakhera ML. 2015. Leaf litter decomposition and nutrient dynamics in four tree species of dry deciduous forest. Trop Ecol. 56(2):191-200.

- Berg B, McClaugherty C. 2014. Plant litter: decomposition, humus formation, carbon sequestration. 3rd ed. Berlin: Springer-Verlag.

- Cools N, Vesterdal L, De Vos B, Vanguelova E, Hansen K. 2014. Tree species is the major factor explaining C:N ratios in European forest soils. For Ecol Manage. 311:316.

- Cremer M, Kern NV, Prietzel J. 2016. Soil organic carbon and nitrogen stocks under pure and mixed stands of European beech, Douglas fir and Norway spruce. For Ecol Manage. 367:30-40.

- Díaz-Pinés E, Rubio A, van Miegroet H, Montes F, Benito M. 2011. Does tree species composition control soil organic carbon pools in Mediterranean mountain forests? For Ecol Manage. 262:1895-1904.

- Fernández IJ, Son Y, Kraske CR, Rustad LE, David MB. 1993. Soil carbon dioxide characteristics under different forest types and after harvest. Soil Sci Soc Am J. 57:11151121.
- Fischer RF, Binkley D. 2012. Ecology and Management of Forest Soils. 4th Ed. New York: John Wiley \& Sons.

- Fonseca F, Figueiredo T. 2010. Impact of tree species replacement on carbon stocks in forest floor and mineral soil. In: Proceedings of the IUFRO-Landscape Ecology International Conference; 2010 Sept 21-27; Bragança, Portugal; Forest Landscapes and Global Change: New Frontiers in Management, Conservation and Restoration. p. 557-562.

- Fonseca F, Figueiredo T. 2012. Carbon in soils of Montesinho Natural Park, Northeast Portugal: preliminary map-based estimate of its storage and stability. Spanish Journal of Rural Development 3(1):71-78.

- Fonseca F, Figueiredo T, Ramos MAB. 2012. Carbon storage in the Mediterranean upland shrub communities of Montesinho Natural Park, northeast of Portugal. Agroforestry Systems 86:463-475.

- Fyles JW, Fyles IH, Feller MC. 1991. Nitrogen mineralization characteristics of forest floor organic matter on slash-burned sites in coastal British Columbia. Can J For Res. 21:235-241.

- Guendehou GS, Liski J, Tuomi M, Moudachirou M, Sinsin B, Makipaa R. 2014. Decomposition and changes in chemical composition of leaf litter of five dominant tree species in a West African tropical forest. Trop Ecol. $55: 207-220$

- Gurmesa GA, Schmidt IK, Gundersen P, Vesterdal L. 2013. Soil carbon accumulation and nitrogen retention traits of four tree species grown in common gardens. For Ecol Manage. 309:47-57.

- Herrero C, Turrión B, Pando V, Bravo F. 2016. Carbon content of forest floor and mineral soil in Mediterranean Pinus spp. and Oak stands in acid soils in Northern Spain. Forest Syst. 25(2):e065.

- Hobbie SE. 1996. Temperature and plant species control over litter decomposition in Alaska tundra. Ecol Monogr. 66:502-522.

- INMG. 1991. Normais Climatológicas da Região de "Trás-os-Montes e Alto Douro" e "Beira Interior" Correspondentes a 1951-1980. Fascículo XLIX, Volume 3, $3^{\text {a }}$ Região, Lisboa.

- ISO. 1995. Soil quality - determination of organic and total carbon after dry combustion (elementary analysis). International Standard ISO 10694. Geneva (Switzerland): International Organization for Standardization.

- IUSS Working Group 2015. World reference base for soil resources, update 2015. International soil classification system for naming soils and creating legends for soil maps. World Soil Resources Reports 106. Rome: FAO.

- Kaspari M, García MN, Harms KE, Santana M, Wright SJ, Joseph B. Yavitt JB. 2008. Multiple nutrients limit litterfall and decomposition in a tropical forest. Ecol Lett. 11:35-43. 
- Keith DM, Johnson EA, Valeo C. 2010. Moisture cycles of the forest floor organic layer ( $\mathrm{F}$ and $\mathrm{H}$ layers) during drying, Water Resour Res. 46:W07529.

- Kooch Y, Samadzadeh B, Hosseini SM. 2017. The effects of broad-leaved tree species on litter quality and soil properties in a plain forest stand. Catena 150:223229.

- Mahendrappa MK, Foster NW, Weetman GF, Krause HH. 1986. Nutrient cycling in forest soils. Can J Soil Sci. 66(4):547-572.

- Martins A, Azevedo S, Raimundo F, Carvalho L, Madeira M. 2009. Decomposição de folhada de quatro espécies florestais no Norte de Portugal: Taxa de decomposição e evolução da composição estrutural e do teor em nutrientes. Rev Ciências Agrárias 32(1):223-237.

- Martins A, Coutinho J, Costa S, Fonseca F, Madeira M. 2007. A folhada de quatro povoamentos florestais no Norte de Portugal: Produção e concentração e quantidade de nutrientes devolvidos ao solo. Rev Ciências Agrárias 30(2):201-216.

- Marty C, Houle D, Gagnon C, Courchesne F. 2017. The relationships of soil total nitrogen concentrations, pools and $\mathrm{C}: \mathrm{N}$ ratios with climate, vegetation types and nitrate deposition in temperate and boreal forests of eastern Canada. Catena 152:163-172.

- Merzouki A, Lossaint P, Billes G, Rapp M. 1990. L'effet d'une coupe à blanc sur le compartiment biomasse microbienne d'un sol rouge méditerranéen. Bull Ecol. 21(2):83-88.

- Mueller KE, Eissenstat DM, Hobbie SE, Oleksyn J, Jagodzinski AM, Reich PB, Chadwick OA, Chorover J. 2012. Tree species effects on coupled cycles of carbon, nitrogen, and acidity in mineral soils at a common garden experiment. Biogeochemistry 111:601-614.

- Neirynck J, Mirtcheva S, Sioen G, Lust N. 2000 Impact of Tilia platyphyllos Scop., Fraxinus excelsior L., Acer pseudoplatanus L., Quercus robur L. and Fagus sylvatica L. on earthworm biomass and physico-chemical properties of loamy topsoil. For Ecol Manage. 133:275286.

- Nunes L, Patrício M, Tomé J, Tomé M. 2010. Carbon and nutrients stocks in even-aged maritime pine stands from Portugal. Forest Syst. 19:434-448.

- Oostra S, Majdi H, Olsson M. 2006. Impact of tree species on soil carbon stocks and soil acidity in southern Sweden. Scand J For Res. 21:364-371.

- Ordóñez JAB, de Jong BHJ, Garcáa-Oliva F, Aviña FL, Pérez JV, Guerrero G, Martínez R, Masera O. 2008. Carbon content in vegetation, litter and soil under 10 different land-use and land-cover classes in the Central Highlands of Michoacan, Mexico. For Ecol Manage. 255:2074-2084.

- Park A. 2015. Carbon storage and stand conversion in a pine-dominated boreal forest landscape. For Ecol Manage. 340:70-81.
- Polglase PJ, Jokela EJ, Comerforf NB. 1992 Phosphorus, nitrogen and carbon fractions in litter and soil of southern pine plantations. Soil Sci Am J. 56:566572.

- Prescott CE, Grayston SJ. 2013. Tree species influence on microbial communities in litter and soil: Current knowledge and research needs. For Ecol Manage. 309:19-27.

- Rapp M. 1984. Répartition et flux de matière organique dans un écosystème à Pinus pinea L. Ann Sci For. 41(3):253-272

- Reich PB, Oleksyn J, Modrzynski J, Mrozinski P, Hobbie SE, Eissenstat DM, Chorover J, Chadwick OA, Hale CM, Tjoelker MG. 2005. Linking litter calcium, earthworms and soil properties: a common garden test with 14 tree species. Ecol Lett. 8(8):811-818.

- Santa-Regina I. 2001. Litterfall, decomposition and nutrient release in three semiarid forests of the Duero basin, Spain. Forestry 74(4):4347-358

- Schroth G, D'Angelo SA, Teixeira WG, Haag D, Lieberei R. 2002. Conversion of secondary forest into agroforestry and monoculture plantations in Amazonia: consequences for biomass, litter and soil carbon stocks after 7 years. For Ecol Manage. 163:131-150.

- Schulp CJE, Nabuurs G-J, Verburg PH, de Waal RW. 2008. Effect of tree species on carbon stocks in forest floor and mineral soil and implications for soil carbon inventories. For Ecol Manage. 256:482-490.

- Shaw MR, Harte J. 2001. Control of Litter Decomposition in a Subalpine Meadow-Sagebrush Steppe Ecotone under Climate Change. Ecol Appl. 11(4):1206-1223.

- Sil A, Fonseca F, Gonçalves J, Honrado J, MartaPedroso C, Alonso J, Ramos M, Azevedo JC. 2017. Analysing carbon sequestration and storage dynamics in a changing mountain landscape in Portugal: insights for management and planning. International Journal of Biodiversity Science, Ecosystem Services \& Management 13(2):82-104.

- Thomsen IK, Petersen BM, Bruun S, Jensen LS, Christensen BT. 2008. Estimating soil C loss potentials from the $C$ to $N$ ratio. Soil Biol Biochem. 40:849-852.

- Trum F, Titeux H, Ranger J, Delvaux B. 2011. Influence of tree species on carbon and nitrogen transformation patterns in forest floor profiles. Ann For Sci. 68(4):837847.

- Vallet P, Meredieu C, Seynave I, Bélouard T, Dhôte JF. 2009. Species substitution for carbon storage: Sessile oak versus Corsican pine in France as a case study. For Ecol Manage. 257:1314-1323.

- van Delft B, de Waal RW, Kemmers RH, Mekkink P, Sevink J. 2006. Field guide Humus Forms: Description and classification of humus forms for ecological applications. Wageningen: Alterra. 
- Vesterdal L, Clarke N, Sigurdsson BD, Gundersen P. 2013. Do tree species influence soil carbon stocks in temperate and boreal forests? For Ecol Manage. 309:418.

- Vesterdal L, Schmidt IK, Callesen I, Nilsson LO, Gundersen P. 2008. Carbon and nitrogen in forest floor and mineral soil under six common European tree species. For Ecol Manage. 255:35-48.

- Wang QK, Wang SL. 2007. Soil organic matter under different forest types in Southern China. Geoderma 142:349-356.

- Wardle DA. 1993. Changes in the microbial biomass and metabolic quotient during leaf litter succession in some New Zealand forest and scrubland ecosystems. Funct Ecol. 7:346-355.

-Wesemael BV. 1993. Litter decomposition and nutrient distribution in humus profiles in some Mediterranean forests in southern Tuscany. For Ecol Manage. 57:99-114.

- Yamashita T, Feiner H, Bettina J, Helfrich M, Ludwig B. 2006. Organic matter in density fractions of water-stable aggregates in silty soils: effect of land use. Soil Biol Biochem. 38:3222-3234.

- Zhang M, Yang H, Xie B, Sun P, Li J, Zou J, Wang Y. 2016. Changes of $C$ and $N$ stocks in the subtropical Dianchi lake watershed in southwest China due to LUCC. Eurasian J Soil Sci. 5(1):17-23. 